\title{
Menelisik Pencegahan Pernikahan Usia Anak di kota Surakarta
}

\author{
Giyartika $^{1}$, Nurhadi ${ }^{\star}$, Yuhastina ${ }^{3}$ \\ Program Studi Pendidikan Sosiologi Antropologi, Universitas Sebelas Maret ${ }^{1,2,3}$ \\ Email:nurhadi@staff.uns.ac.id ${ }^{2^{*}}$ \\ * corresponding author
}

\begin{abstract}
Abstrak
Penelitian ini bertujuan untuk memahami dan menjelaskan upaya pencegahan pernikahan usia anak di Kota Surakarta dalam kajian ilmu sosiologi kependudukan. Wilayah yang dijadikan sampel adalah lima Kampung KB (Kampung Keluarga Berencana) yang tersebar di lima Kecamatan di Kota Surakarta. Data dikumpulkan melalui wawancara mendalam dengan 16 informan dan wawancara terstruktur dengan 48 informan, yang terdiri dari Penyuluh Keluarga Berencana (PKB), Pembantu Pembina Keluarga Berencana Daerah (PPKBD), orangtua, remaja dan aparatur pemerintah. Analisis data dilakukan melalui tiga tahapan, yakni reduksi data atau proses pemilihan, penyederhanaan, abstraksi dan transformasi data mentah, kemudian penyajian data. Penarikan kesimpulan serta verifikasi data dilakukan terus menerus selama penelitian berlangsung. Hasil penelitian menunjukkan bahwa dalam upaya pencegahan pernikahan usia anak di Kota Surakarta terdapat beberapa strategi yang dilakukan oleh berbagai pihak, yakni Penyuluh Keluarga Berencana (PKB), Pembantu Pembina Keluarga Berencana Daerah (PPKBD) dan aparatur pemerintah, sehingga terbentuk suatu pola interaksi sosial dan proses evolusioner atau yang dikenal dengan interaksionisme simbolik. Adapun strategi yang dilakukan diantaranya, melakukan pendekatan budaya, sinergisitas Kelompok Kegiatan (PokTan), semangat berprestasi, membangun intervensi, komitmen dan konsistensi menjalankan program, memaksimalkan penggunaan media sosial dan tertib administrasi.

Kata kunci : interaksionisme simbolik; penyuluh keluarga berencana; pernikahan usia anak; sosiologi kependudukan; surakarta
\end{abstract}

\section{Examining the Prevention of Child Marriage in Surakarta City}

\begin{abstract}
This study aims to understand and explain efforts to prevent child marriage in Surakarta city in the study of population sociology. The areas sampled were five "Kampong KB" (Family Planning Villages) spread over five subdistricts in the city of Surakarta. Data were collected through indepth interviews with 16 informants and structured interviews with 48 informants, consisting of Family Planning Instructors (PKB), Regional Family Planning Assistants (PPKBD), parents, teenagers and government officials. Data analysis was carried out in three stages, namely data reduction or the selection process, simplification, abstraction and transformation of raw data, then data presentation. Conclusions and verification are carried out continuously during the study. The results showed that in the effort to prevent the practice of child marriage in Surakarta city, there were several strategies implemented by various parties, namely Family Planning Instructors (PKB), Regional Family Planning Assistants (PPKBD) and government officials, so as to form a patterns of social interaction and evolutionary processes, also known as symbolic interactionism. The strategies that are carried out include taking a cultural approach, synergy of Activity Groups,
\end{abstract}


enthusiasm for achievement, building interventions, commitment and consistency in running programs, maximizing the use of social media and orderly administration.

Keywords : symbolic interactionism; family planning instructors; child marriage; sociology of population; surakarta

\section{LATAR BELAKANG}

Pernikahan anak atau yang biasa dikenal dengan pernikahan dini merupakan bagian dari isu kependudukan yang selalu menjadi perbincangan global dan dianggap sebagai bencana nasional, karena terjadi di semua kalangan, baik kelompok agama, status sosial ekonomi dan lokasi tempat tinggal bahkan di negara maju sekalipun. Pernikahan anak merupakan salah satu bentuk harmful practices atau praktik yang membahayakan berupa tindak kekerasan, paksaan dan perampasan hak-hak anak dan hak-hak asasi manusia dalam mengembangkan potensi dan melewati proses kematangan fisik maupun non-fisik. Bahkan, perkwinan anak dengan cara paksa demikian dikatakan sebagai bentuk child trafficking (Ajwang \& Warria, 2017). Anak belum memiliki kesiapan matang dalam membangun keluarga baik fisik maupun nonfisik, sehingga rentan terhadap berbagai persoalan kesejahteraan sosial ekonomi, ketahanan keluarga, kesehatan dan pendidikan.

Survei Ekonomi Nasional (Susenas) yang dilakukan oleh Badan Pusat Statistik tahun 2008-2017 menunjukkan bahwa dari 258,7 juta penduduk Indonesia 32,24\% atau 1/3-nya adalah penduduk berusia anak yakni 0 hingga $<18$ tahun dan 1 dari 9 (11\%) perempuan 20-24 tahun menikah sebelum umur 18 tahun (Bappenas 2020). Tingginya praktik pernikahan anak tentunya akan berpotensi membawa risiko atau dampak yang lebih besar dan mengkhawatirkan, terutama pada Human Development Index atau Indeks Pembangunan Manusia (IPM) dan pembangunan berkelanjutan atau Sustainable Development Goals (SDGs). Terlebih risiko atau dampak pernikahan ini dapat terjadi pada lintas generasi (Efevbera dkk., 2017).

Berdasarkan hasil survei nasional sosial dan ekonomi oleh United Nations Children's Fund dan Kidman tahun 2016, pernikahan anak berisiko menghambat setidaknya 8 dari 17 poin SDGs. Diantaranya capaian SDGs poin 1 mengakhiri kemiskinan, poin 2 nengakhiri kelaparan, poin 3 memastikan kehidupan yang sehat dan mendukung kesejahteraan, poin 4 memastikan pendidikan yang inklusif dan setara, poin 5 mencapai kesetaraan gender dan memberdayakan semua perempuan dan anak perempuan, poin 8 mendukung pertumbuhan ekonomi yang inklusif dan berkelanjutan, poin 10 mengurangi ketimpangan dan poin 16 mendukung masyarakat yang damai dan inklusif (Bappenas 2020).

Keluarga yang menikah di usia anak rentan terhadap rendahnya kualitas pendidikan, kesehatan terutama kesehatan ibu dan anak, tingginya risiko kematian ibu dan janin, rendahnya kesejahteraan, Kekerasan Dalam Rumah Tangga (KDRT), perceraian dan penderitaan seumur hidup.

Berdasarkan Survei Kinerja dan Akuntabilitas Program (SKAP) tahun 2019, 6\% perempuan usia 15-19 tahun sudah menjadi ibu, 4,8\% sudah pernah melahirkan dan $1,2 \%$ sedang hamil anak pertama (Badan Perencanaan Pembangunan Nasional Republik Indonesia, 2020). Tingginya kehamilan perempuan dibawah usia 19 tahun berisiko terhadap tingginya kematian bayi per-1000 kelahiran hidup, berdasarkan survei yang dilakukan oleh MAMPU tahun $2020,45 \%$ bayi dibawah usia 1 tahun dari pekawinan anak di perdesaan berisiko kematian sedangkan risiko pada bayi dari pernikahan anak 
di perkotaan adalah 22\% (Badan Perencanaan Pembangunan Nasional Republik Indonesia, 2020). Berdasarkan survei Nasional Sosial dan Ekonomi, United Nations Children's Fund dan Kidman tahun 2016, 53\% anak yang menikah dibawah usia 18 tahun menderita mental disorder dan 1 dari 3 balita mengalami stunting.

Selain itu, laki-laki yang menikah pada usia anak cenderung kurang memiliki pengetahuan komprehensif tentang HIV AIDS dan pengetahuan tentang kontrasepsi modern (Misunas dkk., 2019). Pernikahan anak diestimasikan menyebabkan kerugian ekonomi setidaknya 1,7\% dari Pendapatan Kotor Negara (PDB), anak perempuan yang kawin sebelum usia 18 tahun 4 kali lebih rentan untuk menyelesaikan pendidikan menengah/setara dan rentan terhadap Kekerasan Dalam Rumah Tangga (KDRT) dan perceraian (Bappenas 2020).

Di indonesia, tidak semua pernikahan usia anak adalah kehendak pribadi pelaku, melainkan dorongan bahkan paksaan dari lingkungan sosial, baik orangtua, keluarga maupun dorongan dari anggapan yang berkembang di masyarakat seperti takut dianggap "perawan tua", "daripada berbuat zina lebih baik menikah saja", anggapan "anak adalah beban keluarga" dan justifikasi pandangan agama yang populer di media sosial. Sebagian orang menganggap kasus demikian sebagai hal yang wajar bahkan didukung dan difasilitasi. Anggapan-anggapan pernikahan usia anak terus berkembang dari waktu ke waktu (Efevbera \& Bhabha, 2020). Anggapan serta kurangnya pemahaman akan bahaya pernikahan usia anak demikian yang terus mendorong terjadinya praktik pernikahan anak (Hidayatulloh, 2018). Padahal keluarga yang seharusnya memiliki fungsi perlindungan bagi anak justru menjadi jurang terjerumusnya anak ke dalam persoalan-persoalan pernikahan usia anak, yang baik secara fisik maupun non-fisik anak belum dapat menerimanya.

Sampai dengan saat ini, praktik pernikahan usia anak masih terjadi dalam jumlah besar dan belum menunjukkan penurunan yang signifikan, terutama pada negaranegara berkembang dan daerah perdesaan. UNFPA (United Nations Population Found) melaporkan sekitar 33.000 pernikahan usia anak terjadi setiap harinya di seluruh penjuru dunia (United Nations Population Fund, 2020). Lembaga internasional sampai dengan lembaga daerah, diantaranya UNFPA, BKKBN dan stakeholders lain telah mengupayakan pencegahan praktik pernikahan anak dan pendampingan terhadap keluarga yang menikah di usia anak.

Di Indonesia sendiri, diantaranya adalah dengan dibentuknya Penyuluh Keluarga Berencana (PKB) dan Kampung Keluarga Berencana untuk mendorong kesuksesan program "Bangga Kencana" atau sebelumnya dinamakan sebagai program Kependudukan Keluarga Berencana dan Pembangunan Keluarga (KKBPK). Program ini dilaksanakan di lintas lini masyarakat dan pada daerah-daerah tertentu yang memiliki risiko terhadap persoalan-persolan kesejahteraan dan ketahanan keluarga.

Penyuluh Keluarga Berencana (PKB) merupakan Pegawai Negeri Sipil (PNS) yang memenuhi standar kompetensi dan kualifikasi tertentu yang diberi tugas tanggungjawab, wewenang dan hak secara penuh oleh pejabat yang berwenang sebagai jabatan fungsional tertentu untuk melaksanakan kegiatan penyuluhan, pelayanan, evaluasi dan pengembangan program Kependudukan Keluarga Berencana dan Pembangunan Keluarga (KKBPK) atau "Bangga Kencana" (Peraturan Kepala BKKBN Tentang Pendayagunaan Tenaga Penyuluh Kependudukan, Keluarga Berencana Dan Pembangunan Keluarga, 2017). Sedangkan Kampung Keluarga Berencana sendiri merupakan pusat kegiatan untuk meningkatkan kualitas hidup 
masyarakat di tingkat kampung atau yang setara melalui program KKBPK atau "Bangga Kencana" serta pembangunan sektor terkait lainnya dalam rangka mewujudkan keluarga kecil berkualitas (BKKBN, 2019). Selain itu, kegiatan-kegiatan di Kampung KB sendiri juga merupakan suatu bentuk pendidikan non-formal dalam sistem sepanjang hayat, karena disesuaikan dengan kebutuhan masyarakat setempat tanpa mengenal usia (Yatimah \& Karnadi, 2014).

Dibentuknya Penyuluh Keluarga Berencana (PKB) dan Kampung Keluarga Berencana diharapkan mampu mengurangi praktik pernikahan anak begitupun dengan dampak yang ditimbulkan, akan tetapi sampai saat ini praktik pernikahan anak masih terjadi dalam jumlah besar begitupun dengan dampak yang ditimbulkan. Saat ini Badan Kependudukan dan Keluarga Berencana Nasional (BKKBN) hanya bekerjasama dengan 23.500 penyuluh untuk 80 ribu desa dan dibantu oleh 9.000 penyuluh honorer (Republika.co.id, 2019). Sehingga interaksi sosial dalam persebaran informasi dan edukasi belum merata atau maksimal terutama pada daerah-dareah terpencil, terluar dan daerah tertentu lainnya. Padahal mereka rentan terhadap terjadinya praktik pernikahan anak, rendahnya kesejahteraan dan ketahanan keluarga. Akan tetapi, beberapa wilayah yang dengan adanya Kampung Keluarga Berencana dan pendampingan dari Penyuluh Keluarga Berencana (PKB) mampu membawa perubahan dan peningkatan baik pemahaman maupun kesejahteraan masyarakat. Diantaranya adalah beberapa Kampung Keluarga Berencana di Kota Surakarta.

Terbentuk suatu pola interaksi sosial dalam persebaran informasi dan edukasi pada wilayah tersebut, yang mendorong terjadinya proses evolusioner tentang pandangan dan praktik pernikahan anak. Hal demikian berdampak pada rendahnya kasus praktik pernikahan anak dan tentunya mengurangi risiko dari pernikahan anak.

Beberapa penelitian baik terkait faktor pernikahan anak, dampak pernikahan anak dan upaya pencegahannya telah dilakukan. Akan tetapai sampai saat ini kesenjangan pengetahuan tetap ada dalam memahami tren, pendorong dan pendekatan untuk mengakhiri pernikahan usia anak terutama untuk memahami apa yang dibutuhkan untuk mencapai hasil dalam skala besar (Joe Svanemyr, 2015). Diantaranya penelitian faktor pernikahan anak yang dilakukan oleh Rumble di Indonesia tentang eksplorasi empiris faktor penentu perkawianan anak di Indonesia. Rumble menemukan bahwa pendidikan, kekayaan dan media memiliki potensi mendorong terjadinya praktik pernikahan anak di Indonesia, begitupun dengan tempat tinggal perdesaan juga merupakan faktor risiko yang sama. Terdapat variasi yang signifikan menurut wilayah, yang menunjukkan adanya peran faktor agama, etnis, dan keragaman geografis lainnya. Dalam hal ini, Rumble mengungkapkan bahwa terdapat kesenjangan pemahaman determinan pernikahan anak di Indonesia (Rumble, 2018).

Selain itu penelitian upaya pencegahan praktik pernikahan anak juga dilakukan oleh Tisdal dan Parra tentang tantangan partisipasi sekelompok aktivis anak di Bangladesh dalam upaya mengakhiri pernikahan anak. Dalam penelitian tersebut Tisdal dan Parra menemukan bahwa pentingnya "bayangan hukum" untuk membangun modal politik anak-anak yang mendukung ruang dan waktu bagi anak-anak untuk bergerak sejalan dengan tuntutan pendidikan (Tisdall \& Cuevas-Parra, 2020).

Dari beberapa penelitian yang telah dilakukan, penelitian ini memiliki kebaruan pendekatan, yakni menggunakan pendekatan interaksionisme simbolik Mead dengan Mind-Self-Society dalam melihat strategi upaya pencegahan praktik pernikahan anak, diantaranya, bagaimana pola interaksi sosial yang terbentuk dan bagaimana proses 
evolusioner pandangan pernikahan anak yang terjadi di lingkungan Kampung KB Kota Surakarta.

Harapannya hasil penelitian serta analisis yang dilakukan dapat memberikan gambaran strategi dan proses dalam upaya pencegahan praktik pernikahan anak di Kota Surakarta yang nantinya dapat digunakan sebagai sumber informasi, edukasi, bahan pertimbangan maupun contoh atau panduan baik dalam menjalankan program "Bangga Kencana" dalam melakukan upaya pencegahan terhadap praktik pernikahan anak maupun penelitian lanjutan.

\section{METODE PENELITIAN}

Penelitian ini dilakukan di lima Kampung Keluarga Berencana yang tersebar di lima Kecamatan di Kota Surakarta, diantaranya Kampung KB percontohan di Kota Surakarta yakni Kampung KB Pucangsawit dan 4 Kampung KB lainnya diantarnya, Kampung KB Panularan, Kampung KB Nusukan, Kampung KB Mojo dan Kampung KB Serengan. Lokasi dipilih berdasarkan Kampung KB yang melaksanakan kegiatan Bina Keluarga Remaja (BKR) serta Pusat Informasi dan Konseling Remaja (PIK-R) secara aktif maupun sebaliknya, memiliki kelengkapan rumah data dan sebaliknya, kelengkapan struktur kepengurusan, tingkat partisipasi masyarakat yang tinggi maupun rendah dan Kampung KB yang mengalami kendala yang berbeda dalam menjalankan program.

Penelitian ini menggunakan metode dan pendekatan deskriptif kualitatif yakni menganalisis, menggambarkan dan meringkas kondisi serta situasi berupa hasil wawancara dan pengamatan dilapangan dengan pengambilan sampel menggunakan teknik sampling yang bersifat pusrposive sampling, atau memilih sampel dengan dasar tujuan. Pengumpulan data primer dilakukan pada bulan Oktober 2020 sampai dengan Desember 2020.

Informan dalam penelitian ini terbagi menjadi tiga jenis informan yakni informan kunci, informan inti dan informan pendukung dengan total 64 informan, diantaranya; (1) informan kunci yakni Kepala Dinas Pengendalian Penduduk dan Keluarga Berencana (selanjutnya disingkat DPPKB) Kota Surakarta yang memiliki data, pelaksana dan penanggunjawab program "Bangga Kencana", mengetahui karakteristik masyarakat, pernikahan anak di Kota Surakarta dan perkembangan program, (2) informan inti adalah Penyuluh Keluarga Berencana (PKB) sebagai petugas lapangan yang melakukan penyuluhan, orangtua dan remaja Kota Surakarta yang rentan terhadap terjadinya praktik pernikahan anak, (3) informan pendukung-nya adalah Lurah dan Bagian Pemberdayaan Masyarakat tingkat Kelurahan di Kota Surakarta yang memahami karakteristik wilayah di lini masyarakat Kelurahan, Pembantu Pembina Keluarga Berencana Daerah (PPKBD) tingkat Kelurahan dan Sub PPKBD di tingkat RW sebagai tangan kanan atau pelaksana program di tingkat lini masyarakat, Ketua dan Fasilitator Bina Keluarga Remaja (BKR) sebagai penanggungjawab dan pelaksanan program pencegahan praktik pernikahan anak pada orangtua, serta ketua Pusat Informasi dan Konseling Remaja (PIK-R) di Kota Surakarta sebagai pelaksana dan penanggungjawab program dari remaja oleh remaja dan untuk remaja. Sedangkan data sekunder diperoleh dari instansi terkait dan studi kepustakaan yang berkaitan dengan topik penelitian.

Data primer yang dikumpulkan melalui wawancara langsung, observasi dan dokumentasi. Data terdiri atas interaksi sosial yang terjalin antar komponen, strategi upaya pencegahan praktik pernikahan anak yang telah dilakukan, kendala dalam 
melakukan upaya pencegahan praktik pernikahan anak dan strategi dalam mengatasi kendala upaya pencegahan pernikahan anak.

Analisis data dilakukan dengan menggunakan komponen dalam Analisis Data (Interactive Models) oleh Miles dan Huberman, yakni melalui tiga tahapan, diantaranya reduksi data atau proses pemilihan penyederhanaan, abstraksi dan transformasi data mentah yang ada dalam semua bentuk catatan dan dokumen lapangan, kemudian penyajian data, hal demikian bertujuan untuk memudahkan peneliti dalam memahami gambaran secara keseluruhan atau bagian tertentu dari penelitian dan melakukan penarikan kesimpulan serta verifikasi yang dilakukan terus menerus selama penelitian berlangsung.

\section{HASIL DAN PEMBAHASAN}

\section{Faktor dan Dampak Praktik Pernikahan Usia Anak di Kota Surakarta}

Kota Surakarta merupakan wilayah perkotaan dengan fasilitas dan teknologi yang memadai dan padat penduduk, terdapat lebih dari 1 juta jiwa dalam luas wilayah 44,04 km2 berdasarkan catatan Badan Pusat Statistik Kota Surakarta Tahun 2019. Padatnya penduduk dan kemajuan teknologi di Kota Surakarta berpotensi membawa dampak pada beragam persoalan, diantaranya ketimpangan sosial ekonomi dan pergaulan bebas yang rentan terhadap terjadinya kasus pernikahan anak. Berdasarkan dari Data Konsolidasi Bersih (DKB) yang diterbitkan oleh Direkotorat Jendral Kependudukan dan Pencatatn Sipil (Ditjen Dukcapil) Kota Surakarta pada tahun 2018, tercatat sebanyak 408 anak remaja usia 15-19 tahun yang telah memiliki status kawin (Ditjen Dukcapil Surakarta 2018).

Lurah dan bagian Pemberdayaan Masyarakat Kelurahan di Kota Surakarta, mengatakan bahwa, pernikahan anak di wilayah mereka mayoritas terjadi karena kehamilan di luar nikah dan dorongan dari orangtua. Seringkali pengaruh buruk pergaulan dan media sosial serta kurangnya pengawasan dari orangtua melatarbelakangi terjadinya kehamilan di luar nikah pada usia anak. Selain itu, mayoritas orangtua memiliki anggapan bahwa dengan menikahkan anaknya ketika ada yang mau dan dianggap mampu, orangtua akan menikahkannya. Orangtua memiliki keyakinan bahwa dengan jalan pernikahan dapat mengurangi beban keluarga.

Dalam hal demikian, Kepala DPPKB kota Surakata menjelaskan bahwa, seringkali kasus praktik pernikahan usia anak ini terjadi karena implementasi delapan fungsi keluarga pada kasus praktik pernikahan usia anak belum baik atau optimal. Padahal, pelaksanaan fungsi keluarga yang optimal dapat mendukung terwujudnya sumber daya manusia dan keluarga yang berkualitas (Herawati dkk., 2014). Delapan fungsi keluarga demikian diantaranya, fungsi agama, fungsi kasih sayang, fungsi perlindungan, fungsi sosial budaya, fungsi reproduksi, fungsi sosialsiasi dan pendidikan, fungsi ekonomi dan fungsi pembinaan lingkungan. Padahal, keluarga merupakan kunci dari pembangunan karakter anak, akan tetapi seringkali orangtua baik ibu maupun ayah tidak memiliki waktu untuk memberikan kasih sayang, mendidik dan memantau perkembangan anak. Sehingga anak cenderung mencari kesenangan di tempat lain dan terjerumus kedalam pergaulan bebas yang menyebabkan kehamilan di luar menikah.

Selain itu kasus pernikahan usia anak demikian juga terjadi karena kurangnya pemahaman orangtua yang menikah pada usia anak terhadap pola asuh anak, sehingga terjadi kasus praktik pernikahan anak lintas generasi (Herawati dkk., 2017). Faktor pendidikan rendah serta pengetahuan dan pemahaman tentang kesehatan reproduksi 
juga merupakan faktor yang mendorong terjadinya praktik pernikahan usia anak di Kota Surakarta (Erwinsyah dkk., 2018).

Praktik pernikahan anak demikian, tentunya membawa beberapa dampak yang mengkhawatirkan terutama pada risiko kekerasan dan pelecehan (Svanemyr dkk., 2012). Dampak pernikahan anak yang terjadi di setiap wilayah di Kota Surakarta memiliki tingkat kasus yang berbeda-beda, diantaranya adalah KDRT (Kekerasan Dalam Rumah Tangga), perceraian dan status anak. Di Kelurahan Pucangsawit praktik pernikahan usia anak terjadi setiap tahunnya dan kasus pernikahan usia anak ini di proses secara hukum. Hal demikian ditunjukkan dengan data pernikahan anak dalam lima tahun terakhir pada Tabel.1 berikut:

Tabel 1. Data Kasus Praktik Pernikahan Anak KelurahanPucangsawit Periode Januari 2016-Oktober 2020.

\begin{tabular}{|c|c|c|c|c|c|c|c|c|c|c|c|c|c|c|c|}
\hline \multirow[t]{3}{*}{ Tahun } & \multicolumn{15}{|c|}{$\begin{array}{l}\text { Data Kasus Praktik Pernikahan Usia Anak Kelurahan } \\
\text { Pucangsawit, Kecamatan Pucangsawit Kota Surakarta } \\
\text { Berdasarkan RW Periode Januari 2016-Oktober } 2020\end{array}$} \\
\hline & \multicolumn{15}{|c|}{ Jumlah kasus per RW } \\
\hline & I & II & IIII & IV & V & $\mathrm{VI}$ & VII & VIIII & IX & $\mathrm{X}$ & $\mathrm{XI}$ & XII & XIII & XIV & $X V$ \\
\hline 2016 & 0 & 0 & 0 & 1 & 0 & 0 & 1 & 0 & 0 & 2 & 1 & 0 & 0 & 0 & 0 \\
\hline 2017 & 0 & 1 & 0 & 0 & 1 & 1 & 0 & 0 & 1 & 0 & 1 & 0 & 0 & 1 & 0 \\
\hline 2018 & 0 & 0 & 1 & 0 & 0 & 0 & 1 & 0 & 0 & 1 & 0 & 0 & 0 & 1 & 0 \\
\hline 2019 & 1 & 0 & 0 & 0 & 0 & 0 & 0 & 1 & 0 & 1 & 0 & 0 & 5 & 0 & 1 \\
\hline 2020 & 1 & 0 & 1 & 1 & 0 & 0 & 0 & 0 & 0 & 2 & 0 & 0 & 2 & 0 & 1 \\
\hline Total & 2 & 1 & 2 & 2 & 1 & 1 & 2 & 1 & 1 & 4 & 2 & 0 & 7 & 2 & 2 \\
\hline
\end{tabular}

Sumber : Data Pernikahan Kelurahan Pucangsawit Periode Januari 2016-Oktober 2020

Berdasarkan tabel tersebut pada tahun 2020 terdapat 8 kasus praktik pernikahan anak yang tercatat di Kelurahan dan di proses secara hukum. Sedangkan pada Kelurahan Panularan hanya ada 1 kasus praktik pernikahan anak pada tahun 2020 yang tercatat dan di proses secara hukum, akan tetapi lebih dari 5 kasus kehamilan diluar nikah pada usia anak yang tidak diproses secara hukum, sehingga anak yang dilahirkan tidak memiliki akta kelahiran maupun akta keluarga.

Dalam hal ini Kepala DPPKB mengatakan bahwa hal demikian terjadi karena kurangnya tanggungjawab baik dari orangtua maupun keluarga terhadap ibu maupun anak yang dilahirkan, mereka cenderung membiarkan hal demikian terjadi tanpa ada usaha atau tindakan apapun, padahal baik pemerintah maupun pihak terkait telah mengusahakan pelayanan semaksimal mungkin.

Hal demikian juga terjadi pada kasus KDRT dan perceraian di Kota Surakarta. Berbagai upaya pencegahan dan pendampingan telah dilakukan baik oleh pihak pemerintah daerah, kelurahan hingga tokoh masyarakat setempat dan stakeholders terkait. Akan tetapi berdasarkan keterangan dari bagian pemberdayaan masyarakat kelurahan di Kota Surakarta menjelaskan bahwa, mayoritas keluarga yang terjerat kasus KDRT enggan untuk melapor, meminta bantuan maupun perlindungan. Sedangkan, warga yang berani melapor dan meminta perlindungan dan telah diberikan pendampingan, kasus KDRT masih tetap berlanjut hingga saat ini dengan alasan iba.

Seringkali tekanan ekonomi berpengaruh negatif signifikan terhadap ketahanan keluarga (Herawati dkk., 2017). Kurangnya komunikasi, kesalahpahaman dan perdebatam ekonomi menjadi pemicu terjadinya kasus KDRT yang rentan terhadap 
ketahanan keluarga atau terjadinya kasus perceraian, yang dapat berdampak buruk baik bagi suami, isteri maupun anak.

Sampai saat ini, Dinas Pengendalian Penduduk dan Keluarga Berencana Kota Surakarta telah mengupayakan edukasi terkait pencegahan praktik pernikahan usia anak dengan melakukan intervensi dengan kurang lebih 54 stakeholders, baik lembaga nasional maupun daerah dan stakeholders terkait yang terdiri dari lembaga pendidikan, lembaga kesehatan, tokoh agama dan tokoh masyarakat. Terdapat 12 Kampung KB yang tersebar di 5 kecamatan di Kota Surakarta, 374 Kelompok Kegiatan, 27 Pusat Informasi dan Konseling Remaja dan 36 Penyuluh Keluarga Berencana. Dengan membangun intervensi demikian tentunya dapat mendorong berkurangnya kasus praktik pernikahan usia anak (Rasmussen dkk., 2019).

\section{Interaksionisme Simbolik Mead dalam pencegahan perkawinan usia anak}

Pernikahan anak merupakan fenomena masyarakat yang memicu perhatian berbagai pihak. Dalam kasus seperti ini Mead menyebutnya sebagai society, dimana proses sosial berupa anggapan-anggapan wajar pernikahan usia anak, diantaranya anggapan anak adalah beban dan justifikasi pandangan agama menjadi pemicu terjadinya praktik pernikahan anak dalam jumlah besar. Terlebih didorong oleh populernya ajakan praktik pernikahan anak melalui media sosial dengan menyertakan hashtag \#nikahmudanikahkaya, \#nikahmudalillah, \#nikahmudaasik dan lainnya. Padahal justifikasi pandangan agama terkait pernikahan anak demikian pada hakikatnya tidak sejalan dengan maqashid al-nikah yaitu membangun keluarga sakinah, mawaddah dan rahmah (Musfiroh, 2016).

Hal demikian mendorong terbentuknya pikiran (Mind) bahwa anggapan pernikahan anak adalah hal yang wajar bahkan perlu dilakukan dan terbentuknya diri (Self) untuk melakukan praktik pernikahan anak. Tentunya hal demikian menjadi tantangan tersendiri baik bagi lembaga pemerintah maupun pihak lain dalam mengupayakan pencegahan pernikahan anak, baik praktik maupun ajakan menikah usia anak.

Setiap wilayah memiliki anggapan atau pandangan tentang pernikahan anak yang berbeda-beda, Mead mengatakan hal demikian tergantung pada dominasi antara "Aku" dan "Diriku", Mead mengatakan bahwa pada wilayah dengan dominasi diri "Aku" memiliki kemajuan dalam berpikir lebih modern dari wilayah dengan dominasi "Diriku" (Ritzer, 2012). Dalam hal ini, dapat dikatakan bahwa masyarakat yang didominasi oleh diri individu "Aku" sudah memahami bahaya praktik pernikahan anak, tidak mendukung dan melakukan praktik pernikahan anak, sebaliknya dengan masyarakat yang didominasi oleh diri individu "Diriku" yang masih memiliki anggapan-anggapan yang sebenarnya anggapan demikian berpotensi merugikan dan membahayakan diri.

Dominasi diri "Aku", tidak berhenti pada tahap memahami bahaya praktik pernikahan anak dan tidak melakukan praktik pernikahan usia anak, melain kan Mead mengatakan bahwa ada sebuah tindakan sosial dan harapan terhadap individu dalam masyarakat yang berhasil menjadi diri "Aku". Mereka tidak hanya melakukan pencegahan praktik pernikahan anak pada diri mereka sendiri dengan memahami atau tidak melakukan praktik pernikahan anak, melainkan juga melakukan suatu inovasi untuk mengupayakan pencegahan praktik pernikahan anak di lingkungan sosialnya. Individu dengan tindakan demikian menjadi harapan bagi berbagai pihak dan mayoritas individu lain untuk membawa perubahan menuju arah yang lebih baik. 
Adanya tindakan sosial demikian yang dilakukan secara kontinu, akan membentuk suatu interaksi sosial yang dapat membawa perubahan dalam skala besar yakni perubahan pada Society atau masyarakat baru. Mead menyebutnya sebagai suatu proses evolusioner, yakni proses yang cukup panjang dalam pembentukan atau perubahan masyarakat ke arah yang lebih modern. Proses evolusioner ini terbentuk di beberapa wilayah di Kota Surakarta dengan adanya kegiatan-kegiatan dalam upaya pencegahan praktik pernikahan anak melalui program "Bangga Kencana" di lingkungan Kampung KB yang didampingi oleh Penyuluh Keluarga Berencana (PKB).

Dalam upaya melakukan pencegahan praktik pernikahan anak atau menciptakan suatu proses evolusiener baik DPPKB maupun stakeholders lain telah mengupayakan secara optimal dalam menangani kasus tersebut. Mulai dari penatapan kebijakan, strategi pelaksanaan program sampai dengan inovasi kegiatan dan evaluasi atau assessment program kegiatan. Akan tetapi, baik Penyuluh Keluarga Berencana (PKB) maupaun pihak terkait, tentunya mengalami beberapa kendala di wilayahnya masingmasing. Adapun kendala yang dihadapi diantaranya, sebagian keluarga cenderung tertutup dalam menerima informasi maupun edukasi baik dari Penyuluh Keluarga Berencana (PKB) maupun pihak lain, sehingga informasi dan edukasi tidak tersebar rata hingga ke lini masyarakat. Selain itu, banyak tipikal masyarakat ketika menghadiri sosialisasi atau kegiatan lain ada tendensi untuk mendapatkan konsumsi atau pesangon, hal demikian berdampak pada kegiatan yang tidak dapat dilaksanakan secara lebih maksimal karena mempengaruhi keterbatasan anggaran.

Selain itu, Kampung KB di Kota Surakarta juga memiliki kendala pada kurangnya swadaya yang mampu dan mau bekerja sosial guna membantu Penyuluh Keluarga Berencana (PKB) dalam meningkatkan partisipasi masyarakat. Padahal kapasitas kader baik di tingkat kelurahan maupun tingkat RW berbeda-beda, tidak semua kader aktif, ada lansia tidak melek teknologi, ada yang bekerja di pabrik dan ada yang pemalu sehingga komunikasi, kegiatan atau pertemuan sulit untuk dilaksanakan.

Pada kalangan remaja, mayoritas remaja menganggap bahwa metode penyampaian edukasi atau pemberian informasi serta media yang digunakan dianggap kurang menarik, mereka lebih suka mencari informasi sendiri di internet yang terkadang informasi yang mereka dapatkan justru dapat menjerumuskannya pada TRIAD KRR atau tiga risiko yang dihadapi oleh remaja, yakni NAPZA (Narkotika, Alkohol, Psikotropika dan Zat Adiktif lainnya), seks bebas dan pernikahan usia anak.

Selain itu, pada beberapa wilayah, sebelum dibentuk Kampung KB, ada wilayah terbagi menjadi dua kubu karena adanya konflik internal, hal demikian juga berdampak atau menghambat keberjalanan program dengan lebih maksimal, baik upaya edukasi maupun persebaran informasi, karena kegiatan tidak dapat dilakukan secara bersamaan. Padahal, baik tenaga Penyuluh Keluarga Berencana (PKB) maupun pihak lain, serta waktu dan anggaran terbatas. Akan tetapi, harapannya, dengan adanya kegiatan yang dilakukan bersama dan dalam kurun waktu yang cukup lama serta kontinu, dapat membaurkan konflik yang terjadi, sehingga interaksi sosial dapat terjalin dengan lebih optimal. Beberapa kendala demikian, tentunya membawa dampak yang cukup signifikan pada sulitnya proses pembentukan interaksi sosial terlebih menciptakan suatu proses evolusioner, karena akses dengan komponen terkecil dalam masyarakat yakni keluarga terhambat, baik informasi maupun kegiatan edukasi tidak dapat berjalan dengan kontinu dan tersampaikan secara maksimal. 
Dari berbagai kendala demikian dan dampak yang ditimbulkan, ada beberapa upaya atau strategi yang dilakukan baik oleh Dinas Pengendalian Penduduk dan Keluarga Berencana (DPPKB), Penyuluh Keluarga Berencana (PKB), kader maupun stakeholders lain dalam meminimalisir kendala tersebut, yakni melalui komitmen, sinergisitas dan konsistensi dalam menjalankan program agar proses interaksi sosial dapat terbentuk dan mencapai keberhasilan yang maksimal. Penggunaan strategi dalam upaya pencegahan praktik pernikahan anak ini sendiri merupakan hal yang sangat penting untuk dilakukan terlepas dari faktor budaya yang mendorong praktik pernikahan anak (Kalamar dkk., 2016).

Strategi-strategi yang dilakukan di Kota Surakarta diantaranya adalah dengan melakukan pendekatan budaya, yang salahsatunya dilakukan di Lingkungan Kampung KB Pucangswit. Budaya dijadikan sebagai media pendekatan baik kepada orangtua maupun remaja secara seimbang untuk memberikan edukasi dan informasi terkait bahaya praktik pernikahan anak. Pendekatan dilakukan secara seimbang karena, terkadang kendala atau terjadinya suatu kasus datang dari komponen dalam keluarga itu sendiri (Sistiarani dkk., 2018).

Melalui pendekatan demikian informasi dan edukasi lebih bisa diterima dan tersampaikan dengan baik. Dalam melakukan pendekatan budaya, ada dua pendekatan budaya yang dilakukan diantaranya, melalui alat musik band dan lagu kenangan. Orangtua dan remaja yang bermusik dan bernyanyi. Tentunya agar membentuk suatu interaksi sosial kegiatan demikian dilakukan secara rutin, setiap malam minggu untuk lagu kenangan atau lagu lama dan musik bambu pada malam jumat. Pada kegiatan ini Bina Keluarga Remaja (BKR) juga menyampaikan syair-syair yang dirangkum sendiri oleh pemusik, syair berupa pesan-pesan terkait Keluarga Berencana dan Generasi Berencana. Kegiatan tersebut juga sudah memiliki izin dan perjanjian resmi dengan lingkungan RW, Kampung KB dan kelurahan, sehingga kegiatan tersebut sangat didukung dan difasilitasi oleh tokoh setempat. Bukan hanya di Kampung KB Pucangsawit saja, melainkan pendekatan budaya juga dilakukan di Kampung KB Nusukan sekaligus sebagai penanaman fungsi sosial budaya pada masyarakat, terlebih pada keluarga di lingkungan setempat, yakni dengan melakukan kegiatan festival pelestarian budaya yang dilaksanakan setiap tahun pada bulan Muharrom (Suro).

Selain melalui pendekatan budaya, interaksi sosial juga dilaksanakan di kehidupan sehari-hari, baik oleh Pembantu Pembina Keluarga Berencana Daerah (PPKBD) maupun Sub PPKBD dalam menyalurkan informasi dan edukasi serta pemantauan perkembangan keluarga baik untuk program Pos Pelayanan Terpadu (POSYANDU) balita, Keluarga Berencana untuk orangtua maupun Generasi Berencana untuk remaja. Sub PPKBD melakukan pemantauan dan pendampingan kepada ibu yang mengalami kehamilan terutama ibu yang menikah pada usia anak untuk menghindari terjadinya kematian ibu dan anak, stunting, komplikasi saat kehamilan maupun saat melahirkan. Sub Pembantu Pembina Keluarga Berencana Daerah (Sub PPKBD) mengajak, memantau, memberikan edukasi dan informasi kepada ibu hamil untuk melakukan pemeriksaan minimal 4 kali di Puskesmas dan melahirkan dengan bantuan bidan. Di Jawa Tengah kegiatan ini diberi istilah "Jateng Gayeng Nginceng Wong Meteng" yang artinya Jawa Tengah menyenangkan memantau orang hamil.

Setelah ibu melahirkan, Sub Pembantu Pembina Keluarga Berencana Daerah (Sub PPKBD) mengajak ibu untuk mengikuti program POSYANDU terutama bagi keluarga yang menikah usia anak, guna menghindari kematian bayi dan stunting dan 
mengajak ber-KB setelah selesai masa nifas dengan tujuan memberikan jarak pada kehamilan agar terhindar dari risiko-risiko kedepannya. Terlebih, diantara ibu nifas yang belum terpenuhi kebutuhannya akan KB lebih besar, sehingga terdapat potensi besar untuk meningkatkan capaian kesehatan reproduksi perempuan melalui peningkatan akses KB nifas (Spagnoletti et al., 2018). Selain itu Sub PPKBD juga mengajak orangtua untuk mengikuti program Bina Keluarga Balita dengan tujuan edukasi terkait pemantauan perkembangan anak dan edukasi lainnya, seperti pentingnya pemberian ASI eksklusif pada balita untuk menghindari risiko kematian balita (Fanani dkk., 2020).

Selain program POSYANDU dan KB Sub Pembantu Pembina Keluarga Berencana Daerah (Sub PPKBD) juga melakukan pemantauan, mengajak, memberikan edukasi dan informasi terkait program Generasi Remaja (GenRe), membantu Pusat Informasi dan Konseling Remaja (PIK-R) dan Bina Keluarga Remaja (BKR) untuk memastikan remaja dan orangtua yang memiliki remaja teredukasi dengan cukup dan terhindar dari TRIAD KRR atau tiga risiko yang dihadapi oleh remaja, yakni NAPZA (Narkotika, Alkohol, Psikotropika dan Zat Adiktif lainnya), seks bebas dan pernikahan anak. Selain itu kader PPKBD (Pembantu Pembina Keluarga Berencana Daerah) dibantu oleh sub PPKBD melakukan pendataan keluarga secara rutin, yang meliputi PUS (Pasangan Usia Subur), jumlah anggota keluarga, partisipasi KB, jumlah balita dan lansia. Pendataan secara rutin demikian merupakan bentuk dari pendisiplinan bagi masyarakat untuk terus mengikuti program yang dianjurkan oleh pemerintah (Hidayat, 2018).

Di Kampung KB Kota Surakarta, keterbatasan anggaran tidak dianggap sebagai masalah yang sangat krusial, melainkan dapat diatasi dengan mensinergikan beberapa kegiatan yang berkaitan. Dengan mensinergikan kegiatan yang berkaitan, selain dapat dapat memaksimalkan anggaran dan kegiatan, hal demikian juga dapat menghemat waktu dan tenaga. Sinergisitas antar kelompok kegiatan Bina Keluarga Remaja (BKR) dengan Pusat Informasi dan Konseling Remaja (PIK-R), Usaha Peningkatan Pendapatan Keluarga Sejahtera (UPPKS) dengan PIK-R dan BKR. Kegiatan yang sudah dilakukan diantaranya adalah pembuatan bubuk jahe dan pembuatan kerajinan di Kampung KB Kelurahan Pucangsawit yang dibuat oleh orangtua dari UPPKS dan PIK$\mathrm{R}$ sebagai fotografer produk, begitupun ketika kegiatan pelatihan atau sosialisasi yang berkaitan. Di Kampung KB lain seperti Kampung KB Nusukan kegiatan kolaborasi yang dilakukan adalah pada kegiatan budidaya lele dan pembuatan kerajinan dari olahan sampah.

Dalam upaya edukasi dan pemberian informasi sendiri dilakukan dengan menggunakan beragam media baik yang diperoleh dari Badan Kependudukan dan Keluarga Berencana Nasional (BKKBN), Dinas Pengendalian Penduduk dan Keluarga Berencana (DPPKB), maupun inovasi dari Penyuluh Keluarga Berencana (PKB) dan kader agar lebih mudah dipahami dan diterima oleh orangtua maupun remaja. Media yang digunakan diantaranya adalah komik, media permainan seperti ular tangga dan celemek, vidio edukasi, poster, leaflet serta alat peraga lainnya.

Penggunaan media edukasi demikian sangat membantu Penyuluh Keluarga Berencana (PKB) dalam menyampaikan edukasi dan informasi serta orangtua dan remaja dalam menerimanya. Beberapa orang cenderung malu bahkan tertutup untuk bercerita, bertanya bahkan berkonsultasi terkait persoalan yang ia hadapi karena menganggap persoalan sebagai aib, padahal mereka sangat membutuhkan bantuan dan dukungan dari orang lain. Selain itu Penyuluh Keluarga Berencana (PKB) juga 
menyediakan layanan konsultasi baik untuk orangtua maupun remaja yang mengalami kesulitan dalam penyelesaian masalah yang dihadapi atau sekedar bertanya informasi.

Ketika melakukan sebuah permainan dalam kegiatan edukasi dan informasi, permainan ular tangga misalnya untuk kegiatan Bina Keluarga Remaja (BKR) dan Pusat Informasi dan Konseling Remaja (PIK-R), kegiatan dilakukan secara berkelompok, setiap kelompok terdiri dari remaja dan orangtua. Media permainan berupa lembar ular tangga, patung, dadu dan lembar pertanyaan untuk dijawab dan didiskusikan bersama. Permainan dilakukan secara memutar dan masing-masing mendapat pertanyaan seputar permasalahan remaja. Peserta menjawab, kemudian didiskusikan bersama dan diambil kesimpulan. Dalam permainan ini Penyuluh Keluarga Berencana (PKB) berperan mendampingi dan memberikan kesimpulan akhir.

Adanya edukasi melalui permainan mampu mendorong orangtua dan remaja untuk menceritakan tentang permasalahan terkait yang pernah dialami secara tidak langsung dan menyampaikan bagaimana orangtua dan remaja mengatasi persoalan tersebut. Hal demikian tentunya menambah wawasan serta sikap yang dibutuhkan baik orangtua maupun anak remaja dalam keluarga ketika menghadapi persoalan-persoalan TRIAD KRR mapun persoalan remaja lainnya.

Dalam melaksanakan kegiatan-kegiatan pada program "Bangga Kencana" tentunya tidak lepas dari campurtangan stakeholders lain. Semangat berprestasi dan menjaring intervensi juga merupakan hal yang mempengaruhi perkembangan Kampung KB di Kota Surakarta, diantaranya adalah dengan mengembangkan dan memaksimalkan media sosial yakni website Kampung KB. DPPKB Kota Surakarta sendiri bekerjasama dengan lebih dari 50 stakeholders di Kota Surakarta, diantaranya Ikatan Isteri Dokter (IID), Ketua Muslimat Nahdlatul Ulama' (Muslimat NU), Rumah Sakit, Universitas dan Lembaga atau Dinas terkait. Selain itu beberapa Kampung KB sendiri juga menjalin kerjasama dengan beberapa pihak diantaranya Universitas, pabrik, Corporate Social Responsibility (CSR), Organisasi Perangkat Daerah (OPD) dan stakeholder lain untuk membantu permasalahan yang ada di Kampung KB.

Sebagian stakeholders memberikan dukungan berupa jasa yakni menyediakan narasumber dan beberapa melakukan penggandaan media Komunikasi, Informasi dan Edukasi (KIE). Tentunya, dalam hal ini Penyuluh Keluarga Berencana (PKB) memiliki peran besar dalam mendorong kemajuan dari setiap kelompok kegiatan seperti Bina Keluarga Remaja (BKR). Hingga saat ini BKR dan Kelompok Kegiatan lain dari beberapa Kampung KB telah mendapatkan beberapa penghargaan baik dari tingkat kecamatan, tingkat provinsi, bahkan mengikuti kegiatan Nasional. Selain itu pada Kampung KB percontohan di Kota Surakarta yakni Kampung KB Pucangsawit, menerima beberapa kunjungan setiap tahunnya, baik dari lembaga maupun Kampung KB dari kota lain.

Selain menjaring intervensi baik Kader maupun Penyuluh Keluarga Berencana (PKB) memiliki komitmen dan konsistensi dalam menjalankan program, Rencana Kerja Masyarakat (RKM) pada setiap Kelompok Kegiatan benar-benar dijalankan dan dilakukan evaluasi program. Dengan sering melakukan kegiatan pertemuan antara kader Bina Keluarga Remaja (BKR) dengan orangtua, sehingga lebih mempermudah dalam berkoordinasi dan memberikan edukasi terhadap orangtua untuk ikut mengawasi dan membina putra-putrinya yang sudah menginjak remaja, agar pesan Keluarga Berencana dan Generasi Berencana benar-benar tersampaikan.

Selain itu pendekatan, edukasi dan pemberian informasi untuk keluarga yang belum mengikuti program kegiatan di Kampung KB, kader melakukan kunjungan 
kerumah-rumah. Sampai saat ini kunjungan kerumah-rumah baru terlaksana di RW 12 Pucangsawit atau lingkungan Kampung KB Pucangsawit selama 1 kali dalam 3 bulan. Dalam hal ini, tokoh kunci merupakan komponen yang sangat penting dan harus ada di setiap wilayah. la berperan sebagai panutan/role model bagi masyarakat serta motor penggerak berlangsungnya kegiatan Kelompok Kegiatan. Tokoh kunci merupakan tokoh yang berpengaruh dan bisa berkoordinasi dengan Penyuluh Keluarga Berencana (PKB), mampu memahami tujuan dan program yang akan dilaksanakan serta mampu dan bersedia menggerakkan keberjalanan Kelompok Kegiatan.

Tertib administrasi, perencanaan kerja, rumah data dan struktur organisasi juga merupakan hal yang penting untuk dilengkapi. Untuk mencapai tujuan kegiatan maka semuanya dijalankan termasuk tertib administrasi, karena dalam evaluasi penilaian, cek administrasi merupakan hal yang penting.

Dari fenomena pernikahan anak di Kota Surakarta dan beberapa kendala yang dihadapi, melalui strategi upaya yang telah dilakukan tersebut, terjadi suatu proses evolusioner, seperti halnya proses yang dilihat oleh Mead. Terjadi suatu proses evolusioner dari anggapan pernikahan usia anak adalah hal yang wajar menjadi hal yang tidak wajar bahkan menjadi sentimen tersendiri.

Sebelum dibentuknya Kampung Keluarga Berencana dan Penyuluh Keluarga Berencana (PKB) sebagian masyarakat (Society) Kota Surakarta masih didominasi diri "Diriku" dimana sebagian besar masyarakat masih memiliki anggapan bahwa menikah di usia anak merupakan hal yang wajar bahkan perlu dilakukan dan difasilitasi karena beberapa alasan seperti desakan ekonomi, anggapan anak adalah beban keluarga, untuk menghindari zina dan lainnya. Setelah dibentuk Kampung Keluarga Berencana dan pendampingan oleh Penyuluh Keluarga Berencana (PKB) melalui program "Bangga Kencana", yang dijalankan dengan komitmen, sinergisitas dan konsistensi dari Penyuluh Keluarga Berencana, kader, aparat pemerintah dan stakeholders lain mampu membentuk suatu pola interaksi sosial serta tindakan sosial.

Tindakan sosial tersebut berupa inovasi terus-menerus baik dalam metode penyampaian edukasi dan media edukasi seperti pengampaian edukasi melalui pendekatan budaya dan edukasi melalui media permainan ular tangga. Hingga saat ini terbentuklah masyarakat (Society) baru di Surakarta yang memiliki anggapan bahwa wajar usia menikah adalah 19 tahun atau diatas 20 tahun. Sebelum benar-benar memutuskan untuk menikah remaj dan orangtua saling mendukung untuk meningkatkan potensi diri terlebih dahulu sampai anak merasa siap untuk melakukan pernikahan. Anggapan wajar usia menikah demikian merupakan bentuk society baru yang di lihat oleh Mead, yakni dominasi dari diri "Diriku" menjadi diri "Aku", atau dari dominasi objek menjadi subjek atau pelaku perubahan. Baik remaja maupun orangtua tidak melakukan pernikahan di usia anak, tidak mendukung pernikahan usia anak dan ikut serta melakukan edukasi terhadap lingkungan sosialnya untuk tidak melakukan praktik pernikahan usia anak agar terhindar dari dampak-dampak yang ditimbulkan nantinya. Adapun proses evolusioner pandangan pernikahan usia anak demikian dapat dijelaskan melalui Gambar.1 yang dapat dilihat. 
Gambar 1. Proses evolusioner pandangan praktik perkwinan anak di Kota Surakarta

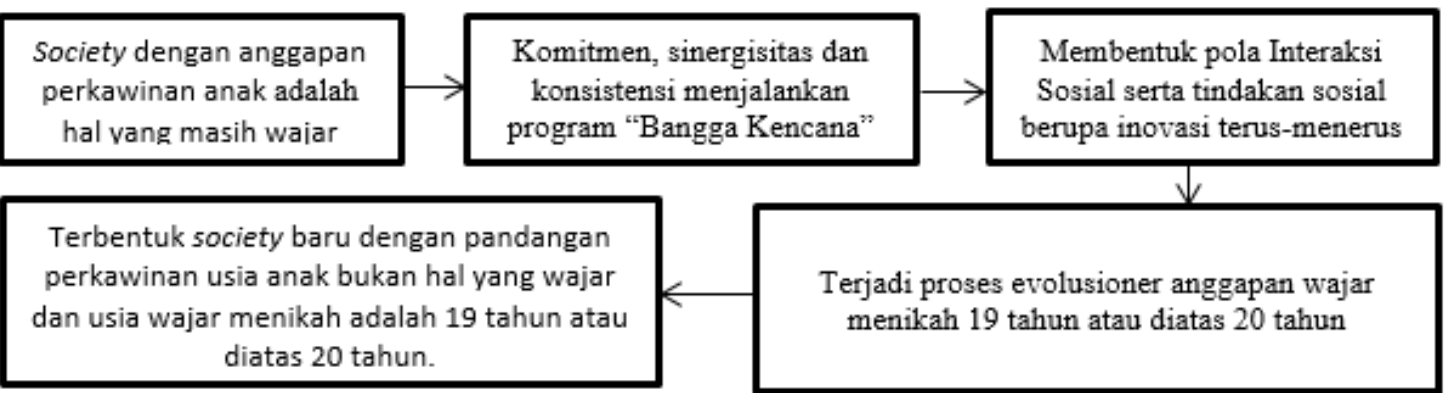

Perubahan anggapan atau pandangan batas usia pernikahan usia anak adalah 19 tahun atau diatas 20 tahun demikian disampaikan dan dibenarkan baik oleh remaja, orangtua, Penyuluh Keluarga Berencana (PKB), kader dan tokoh lainnya di lingkungan Kampung KB Kota Surakarta. Anggapan demikian dapat dilihat pada presentase wajar usia menikah menurut orangtua dan remaja di lingkungan Kampung KB Kota Surakarta pada Gambar.2 berikut:

Gambar 2. Presentase wajar usia menikah menurut orangtua dan remaja di lingkungan Kampung KB Kota Surakarta

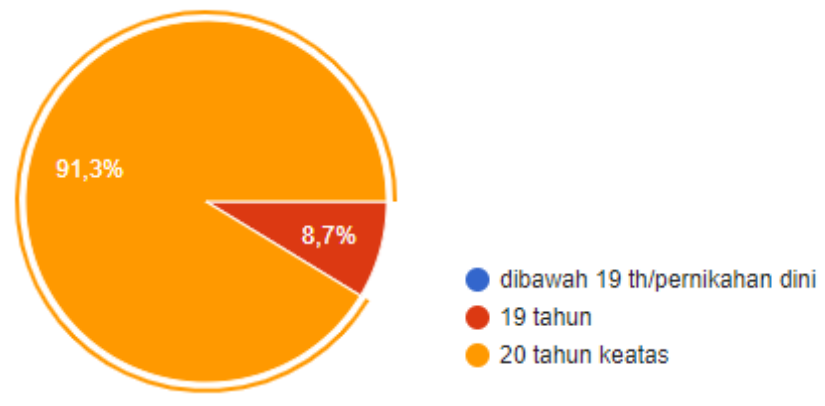

Sumber : Hasil pengolahan data wawancara terstruktur dengan orangtua dan remaja di Kota Surakarta 2020

Proses evolusioner demikian tentunya membawa dampak yang positif terhadap menurunnya status pernikahan usia anak di Kota Surakarta, dimana pada tahun 2017 terdapat 421 anak remaja usia 15-19 yang berstatus kawin dan pada tahun 2018 terdapat 408 anak remaja usia 15-19 yang berstatus kawin (Ditjen Dukcapil Surakarta 2018). Hal demikian tentunya juga berpotensi mengurangi risiko yang ditimbulkan dari praktik pernikahan anak yang lebih rendah.

Perubahan pandangan dari wajar menikah usia anak menjadi tidak wajar menikah usia anak baru terjadi di beberapa lingkungan Kampung Keluarga Berencana saja, karena ada Kampung KB yang memiliki beberapa kendala yang belum terselesaikan sehingga menghambat interaksi sosial dan pembentukan proses evolusioner demikian, begitupun dengan wilayah lain di Kota Surakarta yang bukan merupakan Kampung KB.

\section{KESIMPULAN}

Peningkatan pemahaman dan perubahan anggapan tentang pernikahan usia anak di Lingkungan Keluarga Berencana Kota Surakarta yakni dari pernikahan usia anak adalah hal yang wajar dan perlu dilakukan menjadi pernikahan usia anak adalah hal yang tidak wajar, terjadi melalui proses evolusioner. Terbentuk suatu pola interaksi sosial 
serta tindakan sosial berupa inovasi-inovasi dalam upaya pencegahan praktik pernikahan anak yang dilakukan secara kontinu, komitmen dan sinergisitas dalam menjalankan program "Bangga Kencana".

Strategi atau upaya yang dilakukan dalam mencegah praktik pernikahan anak diantaranya dengan melakukan pendekatan budaya, pendekatan yang seimbang kepada orangtua dan remaja, sinergisitas kelompok kegiatan, semangat berprestasi dan membangun intervensi, peran tokoh kunci, komitmen dan konsistensi PKB dan stakeholders lain dalam mengembangkan program, memaksimalkan media sosial, kunjungan kerumah-rumah dan tertib administrasi. Strategi demikian yang dilakukan dengan kontinu, komitmen dan sinergisitas berbagai pihak, mendorong terbentuknya pola interaksi dan menciptakan suatu proses evolusioner yang membawa perubahan pada pandangan dan peningkatan pemahaman orangtua dan remaja tentang pernikahan usia anak dan menurunnya status pernikahan usia anak serta risiko dampak yang ditimbulkan.

Perubahan pandangan dan peningkatan pemahaman tentang pernikahan anak belum terbentuk di semua lingkungan Kampung Keluarga Berencana Kota Surakarta. Beberapa Kampung KB memiliki kendala yang belum terselesaikan, sehingga menghambat interaksi sosial dan pembentukan proses evolusianer, begitupun dengan wilayah lain di Kota Surakarta yang bukan merupakan Kampung KB.

\section{DAFTAR PUSTAKA}

Ajwang, \& Warria. (2017). Forced Child Marriages as a Form of Child Trafficking. Jurnal Children and Youth Service Review, 79, 274-279.

Badan Perencanaan Pembangunan Nasional Republik Indonesia. (2020). Pernikahan Anak: Dampak, Tantangan Dan Strategi Pencegahannya.

BKKBN. (2019). Kampung KB Sebagai Wahana Pemberdayaan Masyarakat. https://kampungkb.bkkbn.go.id/about\#: :text=Syarat-syarat Pembentukan,Ketiga\%2C-partisipasi-aktif-masyarakat

Efevbera, Y., \& Bhabha, J. (2020). Defining and Deconstructing Girl Child Marriage and Applications to Global Public Health. BMC Public Health, 20.

Efevbera, Y., Bhabha, J., Farmer, P. E., \& Fink, G. (2017). Girl Child Marriage as a Risk Factor for Early Childhood Development and Stunting. Social Science \& Mediine, $185,91-101$.

Erwinsyah, A., Demartoto, \& Supriyadi. (2018). Persepsi Masyarakat Terhadap Pernikahan Usia Dini Di Kelurahan Jebres Kecamatan Jebres Kota Surakarta. Jurnal Analisa Sosiologi, 7, 27-42.

Fanani, M., Rahman, A., \& Dkk. (2020). Community Needs Assessment Base-Education Model to Empower Exclusive Breasfeeding Cadres in Karanganyar District, Central Java - Indonesia. International Medical Jurnal (IMJ), 25, 2067-2078.

Herawati, A., Purwaningsih, A., \& Pudianti, A. (2014). Rural Tourism Community Empowerment Based on Local Resources for Improving Community Welfare: Case on Pentingsari Village, Yogyakarta, Indonesia. Review of Integrative Business \& Economics Research, 3(2), 88-100.

Herawati, T., Sekaring, F. P. T., \& Trijayanti, L. (2017). Tekanan Ekonomi, Srategi Koping, Dan Ketahanan Keluarga Yang Menikah Usia Muda. Jurnal IImu Keluarga \& Konsumen, 10, 181-191.

Hidayat, M. N. (2018). Strategi Implementasi Program Keluarga Berencana Dalam Menekan Angka Fertilitas (Studi Akseptor KB Desa Bandung, Diwek, Jombang). Jurnal IImu Geografi, 23, 107-112.

Hidayatulloh, I. (2018). Persepsi Pernikahan Usia Dini Dan Pemberdayaan Gender (Studi Kasus Desa Pancawati Kecamatan Caringin Kabupaten Bogor). Jurnal 
Pemikiran Dan Penelitian Sosiologi, 3, 1-16.

Kalamar, A. M., Lee-Rife, S., \& Hindin, M. J. (2016). Interventions to Prevent Child Marriege Among Young People in Low-and Middle-Income Countries: A Systematic Review of the Published and Gray Literature. Jurnal of Adolescent Health, 59, 1621.

Misunas, C., Gaston, C. M., \& Cappa, C. (2019). Child Marriage Among Boys in High Prevalence Countries: An Analysis of Sexual and Productive Health Outhcomes.". BMC International Health and Human Rights, 19, 1-16.

Musfiroh, M. R. (2016). Pernikahan Dini Dan Upaya Perlindungan Anak Di Indonesia. Jurnal Hukum Dan Syariah, 8, 67-73.

Peraturan Kepala BKKBN Tentang Pendayagunaan Tenaga Penyuluh Kependudukan, Keluarga Berencana Dan Pembangunan Keluarga, Pub. L. No. No.12/02/Th. MMXVII (2017).

Rasmussen, B., Maharaj, N., Sheehan, P., \& Friedman, H. S. (2019). Evaluating the Employment Benefits of Education and Targeted Interventions to Reduce Child Marriage. Jurnal of Adolescent Health, 65, 16-24.

Republika.co.id. (2019). BKKBN : Hanya Ada 23.500 Penyuluh KB Untuk 80 Ribu Desa. https://republika.co.id/berita/q5jasm396/bkkbn-hanya-ada-23500-penyuluh-kbuntuk-80-ribu-desa

Ritzer, G. (2012). Teori Sosiologi Dari Sosiologi Klasik Sampai Perkembangan Terakhir Postmodern. Pustaka Pelajar.

Rumble, L. (2018). An Empirical Explorations of Female Child Marriage Determinants in Indonesia. BMC Public Health, 18, 1-13.

Sistiarani, C., Hariyadi, B., Munasib, \& Sari, S. M. (2018). Peran Keluarga Dalam Pencegahan HIV/AIDS Di Kecamatan Purwokerto Selatan. Jurnal Ilmu Keluarga \& Konsumen, 11, 96-107.

Spagnoletti, Marie, B. R., Bennett, L. R., Kermode, M., \& Wilopo, S. A. (2018). 'I Want to Enjoy Our Marriage First...but I Got Pregnant Riht Away': A Qualitative Study of Family Planning Understandings and Decisions of Women in Urban Yogyakarta, Indonesia. BMC Pragnancy and Childbirth, 18, 1-14.

Svanemyr, Joar, Chandra-Mouli, V., Sigurdson, C., Christiansen, \& Mbizvo, M. (2012). Preventing Child Marriages: First International Day of the Girl Child "My Life, My Right, End Child Marriage. Jurnal Reproductive Health, 9(31), 1-3.

Svanemyr, Joe. (2015). "Research Priorities on Ending Child Marriage and Supporting Married Girls. Jurnal Reproductive Health, 12(80), 1-4.

Tisdall, E. K. M., \& Cuevas-Parra, P. (2020). Challange for Children's Participation: Child Activism for Ending Child Marriage. Jurnal Children and Youth Service Review, 108, $1-7$.

United Nations Population Fund. (2020). SWOP-Situasi Kependudukan Dunia 2020, Against My Will: Defying the Practices That Harm Women and Girls and Undermine Equality.

Yatimah, D., \& Karnadi. (2014). Pendidikan Non Formal Dan Informal Dalam Bingkai Pendidikan Sepanjang Hayat. Alfabeta. 